\title{
TESTING THE VALIDITY OF WAGNER'S LAW IN BOLIVIA: A COINTEGRATION AND CAUSALITY ANALYSIS WITH DISAGGREGATED DATA
}

\author{
EXAMINANDO LA VALIDEZ DE LA LEY WAGNER EN BOLIVIA: UN \\ ANALISIS DE COINTEGRACION Y CAUSALIDAD CON DATOS \\ DESAGREGADOS
}

\section{ANTONIO N. BOJANIC*}

Universidad Nuestra Señora de La Paz

\begin{abstract}
Nine versions of Wagner's law are examined employing annual time-series data on Bolivia for the period 1940-2010. The analysis is an advance over previous work in several ways. First, the stationarity properties and the order of integration of the data are investigated using the Augmented Dickey-Fuller and the Phillips and Perron tests. Second, the hypothesis of a long-run relationship between different types of government expenditures and income is tested employing the methodology of cointegration analysis. Third, Error Correction Models are utilized to determine the direction of causality between the variables of interest. Lastly, the study comprises a period of seventy years, the longest of its kind for Bolivia. Consistent with Wagner's proposition, bidirectional causality is found between income and government expenditures in six of the nine versions of the law.
\end{abstract}

Keywords: Wagner law, unit roots, cointegration, Error Correction models.

JEL Classification: C10, H50, O10, O54.

\section{Resumen}

Nueve versiones de la Ley Wagner son analizadas utilizando series de tiempo anuales para el período comprendido entre 1940 y 2010. El país de estudio es Bolivia. Este trabajo representa un avance sobre anteriores esfuerzos por las siguientes razones: Primero, las propiedades de estacionariedad

* Professor of Economics, Calle Presbítero Medina \# 2412, La Paz, Bolivia. Ph. 1 (703) 475-7739. E-mail: antonio.bojanic@unslp.edu.bo 
y el orden de integración de los datos son examinados utilizando los tests Dickey-Fuller y Phillips-Perron. Segundo, la hipótesis de una relación a largo plazo entre los diferentes tipos de gasto gubernamental y el producto nacional es analizada utilizando la técnica econométrica de cointegración. Tercero, modelos de corrección de errores son utilizados para determinar la dirección de causalidad entre las variables analizadas. Finalmente, este estudio comprende un periodo de 70 años y representa el estudio mas largo de su tipo para Bolivia. De manera consistente con la proposición de Wagner, los resultados demuestran causalidad bi-direccional entre el producto nacional y el gasto gubernamental en seis de las nueve versiones de la ley.

Palabras clave: Ley Wagner, raíz unitaria, cointegración, modelos de corrección de errores.

Clasificación JEL: C10, H50, O10, O54.

\section{INTRODUCTION}

Over the past decades a vast amount of research has been devoted to examining Wagner's hypothesis which states that as economic activity grows, there is a tendency for government activities to increase ${ }^{1}$. Following Mann's (1980) and Chang et al. (2004) studies, nine different versions of Wagner's law are tested using disaggregated annual time-series data for Bolivia over the period 1940-2010.

The significance of Wagner's law rests on understanding the seemingly inevitable growth and importance of government intervention as an economy becomes more advanced. While this assertion is widely accepted in developed countries ${ }^{2}$, developing nations seem less certain, and the preponderance of evidence against Wagner's law in many studies that concentrate on these nations ${ }^{3}$ may reflect ambivalence towards government intervention ${ }^{4}$.

Testing the validity of the law in Bolivia should produce intriguing results as this country has had a unique relation with its many governments for most of its history as an independent nation. For the period analyzed here, 1940 to 2010, Bolivia has

1 An alternative to Wagner's law is that government expenditures cause economic growth. This hypothesis is known as the 'Keynesian View', but will be largely ignored as the focus of this work is on testing the impact, if any, of economic activity on the size of government expenditures.

2 Refer, for instance, to works by Abizadeh and Gray (1985), Vatter and Walker (1986), Afxentiou and Serletis (1991), Yousefi and Abizadeh (1992), Ahsan et al. (1996), Thornton (1999), and Florio and Colautti (2005), who find supporting evidence for Wagner's Law in various developed countries.

3 Works in this line include Diamond (1977), Abizadeh and Gray (1985), Ansari et al. (1997), Halicioglu (2003), Akitoby et al. (2006), Narayan et al. (2008), Afzal and Abbas (2010), and Zheng et al. (2010).

4 Not all of the studies analyzing the validity of Wagner Law in developing nations produce negative results. Lin (1995), Chletsos and Kollias (1997), and Iyare and Lorde (2004), are but a few of the works that have found largely supportive evidence of Wagner's law in these countries. 
experienced a number of military dictatorships with various ideological leanings. It has endured at least two episodes of severe inflation -in the mid 1950s and during the 1980s- which were the result of misguided government interventions. After the economic collapse of the 1980s, the country experienced a painful but necessary period of structural adjustments that lasted until the turn of the new century, when a backlash to these reforms began taking root. A backtracking of these structural reforms began in 2001 and has lasted until the present, with the current, self-proclaimed populist government bent on reversing all of the so-called 'neoliberal reforms' and establishing a control-and-command economy, with government at the heart and center of all economic activity. With this background in mind, determining whether the hypothesis of Wagner's law holds for a country like Bolivia should indeed be a compelling exercise.

This paper adds to the preceding research on the subject in at least four respects. First, the stationarity properties and the order of integration of the data are empirically investigated using the Augmented Dickey-Fuller (1979, 1981), or ADF test, and the Phillips-Perron (1988), or PP test. Second, the hypothesis of a long-run relationship between government expenditures and income is tested using bivariate cointegrated systems and employing the methodology of cointegration analysis suggested by Johansen (1988), Johansen and Juselius (1990), and Johansen (1994). Third, the issue of causality is determined using Vector Error Correction models for cointegrated variables; standard Granger regressions would be used if a long-run equilibrium relationship was found not to exist. Finally, this is the first study that concentrates solely on Bolivia, utilizing the largest dataset available for the country. In addition to the five most common versions of Wagner's law, four additional versions are tested using disaggregated government expenditures in four key sectors of the Bolivian economy: infrastructure, health, education, and defense. The results show that cointegration holds for the nine versions of the law. However, the causality findings lend support to Wagner's law in only six of the versions tested.

The paper is organized as follows: Section 2 presents the Wagner hypothesis and a sample of studies that have tested its existence in various contexts. The empirical model is presented in Section 3. Section 4 introduces the methodology. Section 5 presents the data. Section 6 presents the results and section seven concludes.

\section{WAGNER'S HYPOTHESIS AND PREVIOUS TESTS}

More than one hundred years ago, Adolph Wagner (1883) formulated the 'Law of the Increasing Extension of State Activity'. He asserted that there is a long run propensity for the scope of government to increase with higher levels of economic development. Wagner's hypothesis deals with the growing relative importance of government activity and has come to be known as Wagner's Law.

According to Wagner, there are three reasons to expect an expanding scope of public activity: first, as nations develop there is an increased complexity of legal relations and communications and it induces government to produce the regulatory framework that will accompany the greater intricacy of relations among economic 
agents. Additionally, increased urbanization and population density forces government to greater public expenditures on law and order and other socioeconomic regulations. Second, as income increases, societies demand more education, entertainment, a more equitable distribution of income, and generally more public services. Wagner felt that the income elasticity of demand for these public services was greater than unity. Finally, the technological needs of an industrialized society require larger amounts of capital infrastructure than are forthcoming from the private sector, hence the need for government to step in to fill in the gap.

Wagner's law has been tested empirically for various countries using both time series and cross-sectional data. Results differ considerably and there is no discernible pattern that emerges from these studies. Abizadeh and Gray (1985) analyze the period 1963-1979 for 55 countries and their findings support Wagner law for wealthier countries but not for the poorest countries. Ram (1986) covers the period 1950-1980 for 63 countries and finds limited support for Wagner's hypothesis. Afxentiou and Serletis (1996) examine six European countries over the period 1961-1991 and find no evidence in support of it. Chang et al. (2004) analyze ten countries over the period 1951-1996 and find supporting evidence in only five of the countries studied. Their study, however, only deals with aggregated data. Diamond (1977), examine the period 1961-1969 for a set of developed and developing countries, including Bolivia, and finds limited supported for the law; for Bolivia, he finds no evidence supporting it. Akitoby et al. (2006) examine the short- and long-term relation between government spending and output for the period 1970-2002 in 51 developing countries, including Bolivia, and find limited evidence supportive of Wagner's law.

Country-specific studies are also abundant. Afxentiou and Serletis (1991), and Ahsan et al. (1996) have analyzed Wagner's Law for Canada, with findings generally in support of the law. Mann (1980), Nagarajan and Spears (1990), Murthy (1993), Ashworth (1994), Hayo (1994) and Lin (1995) have found mixed results for Mexico. Vatter and Walker (1986), and Yousefi and Abizadeh (1992) have examined the law for the United States with results generally in favor of the law. Tobin (2005), analyzing China, regressed the size of the state sector on GDP over the period 1978-2001. Consistent with predictions of Wagner's law, he found that an increase in GDP has a positive effect on the size of the state sector. One problem with Tobin's analysis, however, is that he employed OLS regressions and did not pre-test the stationarity of the data, thus raising the possibility of spurious results. More recently, Afzal and Abbas (2010) analyze the law for Pakistan during the period 1960-2007 and find little evidence in support of it; and Zheng et al. (2010) carry out an empirical analysis of the law in China and find no strong evidence in favor of it.

The more recent set of papers analyzes Wagner's law using disaggregated public expenditure data, hence addressing possible biases due to the use of aggregated data. Gandhi (1971) was the first to test Wagner's law analyzing different components of government expenditure. A sample of more recent works includes Hondroyiannis and Papapetrou (1995), which, in the context of a bivariate approach focuses on Greece; Chlestos and Kollias (1997), also analyze Greece for the period 1953-1993 and find that only the growth of defense expenditures are explained in terms of Wagner's law; Asseery et al. (1999), using disaggregated data measured in both real and nominal 
terms find contradictory results regarding the validity of Wagner's law in Iraq; Biswal et al. (1999), analyze Canada for the period 1950-1995 and find support for the existence of short-run causation between national income and certain components of government current expenditures; Rehman et al. (2010), analyze Pakistan for the period 1971-2006 and find that at the disaggregated level, income causes administrative expenditures, while no causality is found for capital expenditures, debt servicing, and defense expenditures; and Magazzino (2010), who finds evidence in favor of Wagner law in Italy only for spending for passive interests in the long run and for spending for dependent labor income in the short run.

\section{THE EMPIRICAL MODEL}

Despite the abundance of research on the subject, the general manner in which Wagner established a relation between 'economic progress' and the 'growth of state activity', makes it difficult to test the law. In this work, in addition to the five basic specifications tested in Mann (1980) and Chang et al. (2004), four more versions of the law are analyzed utilizing disaggregated data in key sectors of the economy. The period analyzed runs from 1940 to 2010 . The nine empirical versions are the following:
(1a) $\operatorname{lrge}=f($ lry $)$
(1b) $\operatorname{lrge}=f($ lry/pop $)$
(1f) lrginfra $=f($ lry $)$
(1c) $\operatorname{lrge} /$ Pop $=f($ lry/pop $)$
(1g) lrghealth $=f($ lry)
(1d) lrge/lry $=f($ lry/pop $)$
(1h) lrgedu $=f($ lry)
(1e) lrge/lry $=f($ lry $)$
(1i) $\operatorname{lrgdef}=f($ lry)

where $\operatorname{lrge}=$ real total government expenditure, lry $=$ real GDP 5 , lry $/ p o p=$ real GDP per capita, lrge/pop $=$ real total government expenditure per capita, lrge/lry $=$ the share of real total government expenditures on real GDP, lrginfra $=$ real government expenditures on infrastructure, lrghealth = real government expenditures on health, $\operatorname{lrged} u=$ real government expenditures on education, and lrgdef $=$ real government expenditures on defense.

\section{METHODOLOGY}

\section{Unit root tests}

Many macroeconomic time series contain unit roots, which tend to be dominated by stochastic trends. Unit roots are important in determining the stationarity of time series because the presence of non-stationary regressors invalidates many standard hypothesis tests. Among other things, the F-statistic calculated from a regression

5 In this work, the terms 'real GDP' and 'real Income' will be used interchangeably. 
involving nonstationary time-series data does not follow the standard distribution ${ }^{6}$, hence the significance of the test is overstated and spurious results are obtained.

The presence of a stochastic trend is determined by testing the presence of unit roots. Several tests for the presence of unit roots in time series have appeared in the literature (see, for instance, Dickey and Fuller, 1979, 1981; Phillips and Perron, 1988, and Kwiatkowski et al. 1992). In this study, unit roots are tested using both the Augmented Dickey-Fuller (ADF) and the Phillips and Perron (PP) tests.

The Augmented Dickey-Fuller (ADF test) is based on the $t$-ratio of the parameter in the following regression:

$$
\Delta Y_{t}=\alpha_{0}+\alpha_{1} t+\phi Y_{t-1}+\sum_{i=1}^{n} \varphi_{i} \Delta Y_{t-1}+\varepsilon_{t}
$$

where $\Delta$ is the first-difference operator, $\varepsilon_{t}$ is a stationary random error, $Y_{t}$ is the series under consideration (either government expenditures or income), and $n$ is large enough to ensure that $\varepsilon_{t}$ is a stationary random error (white noise). The null hypothesis is that $Y_{t}$ is a nonstationary series, and it is rejected when $\varnothing$ is significantly negative. In practice, the appropriate order of the autoregression, $n$, is unknown and must be determined. The suggestion of Engle and Yoo (1987) is followed and the Akaike (1974) information criterion, AIC, used to determine the optimal specification of Equation (2). The AIC is defined as

$$
\operatorname{AIC}(q)=T \ln \left(\frac{S S R}{T}\right)+2 q
$$

where $T$ is the sample size, $S S R$ is the sum of squared residuals, and $q$ is the number of parameters estimated, which, in this case, is equal to $n+2$. Following Engle and Yoo (1987), the appropriate order of the model is determined by estimating equation (2) for several values of $n$ to find the value minimizing the AIC. Once the appropriate model is determined, the ADF test is applied. The distribution of the ADF statistic is nonstandard and requires the use of critical values tabulated by MacKinnon (1991).

Alternatively, Phillips and Perron (PP test) propose a nonparametric method of controlling for higher-order serial correlation in a series. The test regression for the $\mathrm{PP}$ test is the $\mathrm{AR}(1)$ process:

$$
\Delta Y_{t}=\alpha_{0}+\beta Y_{t-1}+\varepsilon_{t}
$$

6 See Granger and Newbold (1974) for a description and consequences of regressions involving nonstationary time series. 
While the $A D F$ test corrects for higher order serial correlation by adding lagged difference terms on the right-hand side, the PP test makes a correction to the $t$-ratio of the $\phi$ coefficient from Equation (2) to account for the serial correlation in $\varepsilon_{t}$. Two advantages of the PP tests over the ADF tests are that PP tests are robust to general forms of heteroskedasticity in the error term $\varepsilon_{t}$, and there is no need to specify a lag length for the test regression. It is expected that the utilization of both tests will provide greater confidence in the determination of unit roots of the series analyzed in this work.

\section{Cointegration tests}

Once a unit root has been confirmed for a data series, the question is whether there exists some long-run equilibrium relationship among variables. The existence of a long-run equilibrium relationship between economic variables is referred to as cointegration.

According to Engle and Granger (1987), a set of variables, $Y_{t}$, is said to be cointegrated of order $(\mathrm{d}, \mathrm{b})$, denoted $\mathrm{CI}(\mathrm{d}, \mathrm{b})$, if $Y_{t}$ is integrated of order $d$ and there exists a vector, $\beta$, such that $\beta^{\prime} Y_{t}$ is integrated of order (d-b). Cointegration tests are conducted using the method of Johansen (1988) and Johansen and Juselius (1990).

The Johansen method applies the maximum likelihood principle to determine the presence of cointegrating vectors in nonstationary time series. Following Johansen (1988) and Johansen and Juselius (1990), a two-dimensional (2x1) vector autoregressive model is employed with Gaussian errors given by

$$
\begin{gathered}
Y_{t}=A_{1} Y_{t-1}+A_{2} Y_{t-2}+\cdots+A_{k} Y_{t-k}+u+\varepsilon_{t} \\
t=1,2, \ldots, T
\end{gathered}
$$

where $Y_{t}$ is, in turn, government expenditures (real total government expenditures, real total government expenditures per capita, share of real total government expenditures on real GDP, real government expenditures on infrastructure, health, education, and defense) or income (real GDP, real GDP per capita), and $\varepsilon_{t}$ is i.i.d. $N(0, \Sigma)$. After first-differencing on the vector level, the model in error correction form is written as

$$
\Delta Y_{t}=\Gamma_{1} \Delta Y_{t-1}+\Gamma_{2} \Delta Y_{t-2}+\cdots+\Gamma_{k-1} \Delta Y_{t-k+1}-\Pi Y_{t-1}+\mu+\varepsilon_{t}
$$

where $\Gamma_{i}=-I+A_{1}+A_{2}+\ldots+A_{i}$, for $i=1,2, \ldots, k-1$, and $\Pi=I-A_{1}-A_{2}-\ldots-A_{k}$.

The $\Pi$ matrix conveys information about the long-run relationship between the $Y_{t}$ variables (income and government expenditures), and the rank of $\Pi$ is the number of linearly independent and stationary linear combinations of income and government expenditures. 
Testing for cointegration involves testing for the rank, $r$, of the $\prod$ matrix, which is achieved by examining whether the eigenvalues of $\Pi$ are significantly different from zero. The test has three possible outcomes: (a) the $\Pi$ matrix has full column rank implying that the $Y_{t}$ was stationary in levels, (b) the $\prod$ matrix has zero rank, in which case the system is a traditional first-differenced VAR, and (c) the $\Pi$ matrix has rank $r$ with $0<r<2$, implying that there exists $r$ linear combinations of $Y_{t}$ that are stationary or cointegrated. If condition (c) prevails, $\Pi$ can be decomposed into two $2 \times r$ matrices, $\alpha$ and $\beta$, such that $\Pi=\alpha \beta^{\prime}$. The $\beta$ vectors represent the $r$ linear cointegrating relationships such that $\beta^{\prime} Y_{t}$ is stationary. By testing the significance of the $\beta$-coefficients, it can be determined whether the variables are entering the cointegrating relationship significantly. The loading matrix, $\alpha$, represents the errorcorrection mechanism and can be interpreted as speed of adjustment parameters.

Johansen (1988) and Johansen and Juselius (1990) propose two statistics for the determination of the number of cointegrating vectors, or, equivalently, the rank of $\Pi$ : the trace statistic $\left(T_{r}\right)$ and the maximum eigenvalue statistic. In this work, the trace statistic is utilized ${ }^{7}$. Its likelihood ratio statistic is:

$$
T_{r}=-T \sum_{i=r+1}^{p=2} \ln (1-\gamma)
$$

where $\lambda_{r+1}, \ldots, \lambda_{p}$ are the estimated $p-r$ smallest eigenvalues. The null hypothesis to be tested is that there are at most $r$ cointegrating vectors. That is, the number of cointegrating vectors is less than or equal to $r$, where $r$ is 0 or 1 . In each case, the null hypothesis is tested against the general alternative.

It is well known that cointegration tests are very sensitive to the choice of lag length. Here, the Schwartz Criterion (SC) is used to select the number of lags required in the cointegration test. The SC is defined as follows:

$$
S C=\ln \left(\frac{y^{\prime} M y}{T}\right)+K \ln T / T
$$

where $M=I-X\left(X^{\prime} X\right)^{-1} X^{\prime} . T$ is the sample size. Here, $K_{1}$ is chosen so as to numerically minimize $\mathrm{SC}$.

\section{Causality with error correction}

Engle and Granger (1987) demonstrate that if two non-stationary variables are cointegrated, then a vector autoregression in first differences is misspecified. Hence,

7 Even though the trace statistic is the one utilized here, the number of cointegrating equations according to the maximum eigenvalue test are also reported. 
cointegration must be tested before running causality tests ${ }^{8}$. Granger (1986) and Engle and Granger (1987) have proposed the error-correction model (ECM) as a more comprehensive method for testing causality when variables are cointegrated. The cointegrated ECMs of government expenditures (real total government expenditures, real total government expenditures per capita, share of real total government expenditures on real GDP, real expenditures on infrastructure, health, education, and defense) and income (real GDP and real GDP per capita) are as follows:

$$
\begin{gathered}
\Delta Y_{1 t}=\theta_{11}^{m}(L) \Delta Y_{1 t}+\theta_{12}^{n}(L) \Delta Y_{2 t}+\alpha E C T_{1, t-1}+a+\mu_{1 t} \\
\Delta Y_{2 t}=\theta_{21}^{m}(L) \Delta Y_{1 t}+\theta_{22}^{n}(L) \Delta Y_{2 t}+\beta E C T_{2, t-1}+b+v_{2 t}
\end{gathered}
$$

where

$$
\theta_{i j}^{m}(L)=\sum_{l=1}^{M i j} \theta_{i j l} L^{l} \text { and } \theta_{i j}^{n}(L)=\sum_{l=1}^{N i j} \theta_{i j l} L^{l}
$$

and where $\Delta$ is the first-difference operator, $L$ is the lag operator, $Y_{1 t}$ and $Y_{2 t}$ are government expenditures and income -which are first-differenced stationary time series- respectively, and $\mu_{1 t}$ and $v_{2 t}$ are disturbance terms without serial correlation, where $E\left[\mu_{1 t}, \mu_{2 s}\right]=0, E\left[v_{1 t}, v_{2 s}\right]=0, E\left[\mu_{1 t}, v_{2 s}\right]=0$ for all $t \neq s . E C T_{i t-1}$ is the errorcorrection term, lagged one period, which is derived from the long-run cointegrating relationship and included to capture short-run dynamics. The inclusion of these error correction terms, which must be stationary if the variables are cointegrated, differentiates the ECM from the standard Granger causality regressions.

On the basis of equations (9) and (10), unidirectional causality from $Y_{2 t}$ to $Y_{1 t}$ is implied if not only the estimated coefficients on the lagged $Y_{2 t}$ variables in equation (9) are statistically different from zero as a group (based on standard F-statistics), but also the coefficient on the error-correction term in equation (9) is significant, and if the set of estimated coefficients on the lagged $Y_{1 t}$ variables in equation (10) are not statistically different zero. On the other hand, $Y_{1 t}$ causes $Y_{2 t}$ if the estimated coefficients on the lagged $Y_{1 t}$ variable in equation (10) are statistically different from zero as a group, the coefficient on the error-correction term in equation (10) is significant, and if the set of estimated coefficients on the lagged $Y_{2 t}$ variables in equation (9) are not statistically different zero. Bidirectional causality or feedback between $Y_{2 t}$ and $Y_{1 t}$ exists if the set of estimated coefficients on the lagged $Y_{2 t}$ variables in equation (9) are

8 Tano (1993) proposes the use of cointegration and error-correction modeling (ECM) in Granger causality models because of the possibility of spurious co-movement between government expenditures and income. Cointegration analysis attempts to identify conditions under which existing relationships are not spurious. Unlike standard Granger causality which may not detect any causal relationship between variables, with ECM, cointegration ensures that Granger causality exists, at least in one direction. 
statistically significant as a group, the set of estimated coefficients on the lagged $Y_{1 t}$ variables in equation (10) are statistically significant as a group, and the coefficients of error-correction terms in both equations are significant ${ }^{9}$.

As the Granger-causality tests are known to be very sensitive to lag length, some care must be taken when making this choice. Lag lengths are determined using Hsiao's (1979a, 1979b, 1981) sequential procedure. This procedure is based on the Granger definition of causality and Akaike's (1974) minimum final prediction error (FPE) criterion. The FPE criterion is specified as follows:

$$
F P E=\left[\frac{T+k}{T-k}\right]\left(\frac{S S R}{T}\right)
$$

where $T$ is the number of observations, $k$ is the number of parameters estimated, and SSR is the sum of squared residuals. Hsiao (1981) points out that "the FPE criterion balances the risk due to the bias when a lower order is selected and the risk due to the increase of variance when a higher order is selected, and choosing the order of the lags by minimum $F P E$ is equivalent to applying an approximate $F$-test with varying significance levels". This procedure is known as the stepwise Granger-causality technique. However, if government expenditures and income are found to be not cointegrated, then the intertemporal causality relationships in equations (9) and (10) must be estimated without the error-correction terms.

\section{DATA}

The empirical analysis uses annual data on real GDP, real total government expenditures, real government expenditures disaggregated into four key components -infrastructure, health, education, and defense expenditures- and population for the 1940-2010 period ${ }^{10}$. The base year for all variables is 2000 . All data have been obtained from the Statistical Bulletins and the Annual Reports of the Central Bank of Bolivia ${ }^{11}$. Finally, all the data series have been transformed to the logarithmic form to achieve stationarity in variance.

A preliminary appreciation of the data is presented in Figure 1, which illustrates the nine versions of the Wagner Law tested in this work.

\footnotetext{
9 In equations (9) and (10), if the coefficient $\alpha$ in equation (9) (or $\beta$ in equation 10) is significantly different from zero, it would indicate long-run causality from $Y_{2 t}$ to $Y_{1 t}$ (or from $Y_{1 t}$ to $Y_{2 t}$ ).

10 Values for 2010 are preliminary.

11 www.bcb.gob.bo/?q=estadisticas
} 


\section{FIGURE 1}

\section{NINE VERSIONS OF WAGNER LAW}

Version 1:

Real Government Expenditures and Real Income

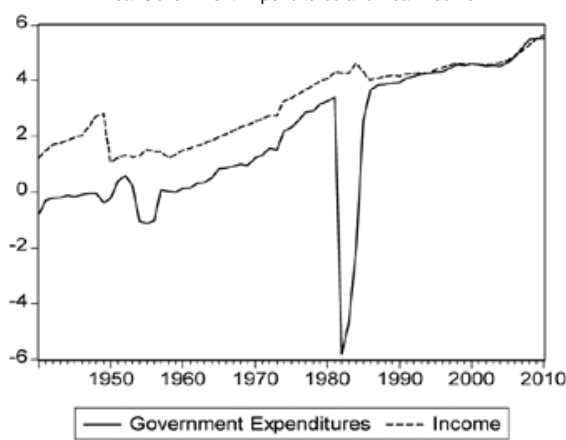

Version 3:

Real Government Expenditures per Capita, Real Income per Capita

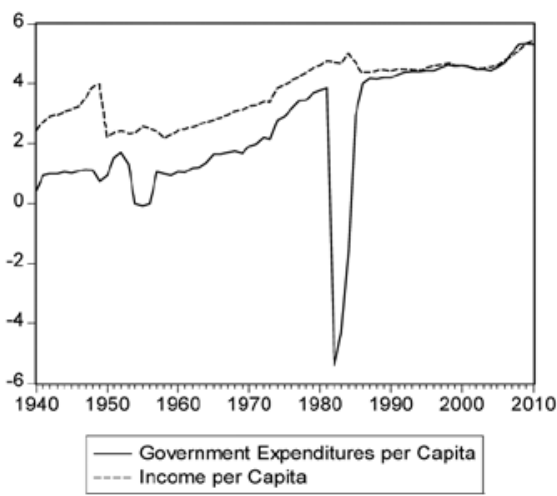

Version 5:

Share of Government Expenditures on Income, Real Income

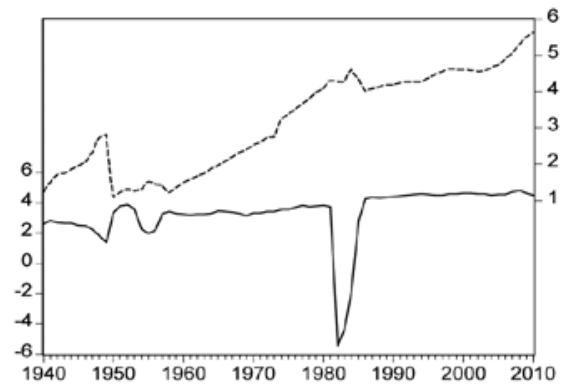

- Share of Government Expenditures on Income Income
Version 2:

Real Government Expenditures, Real Income per Capita

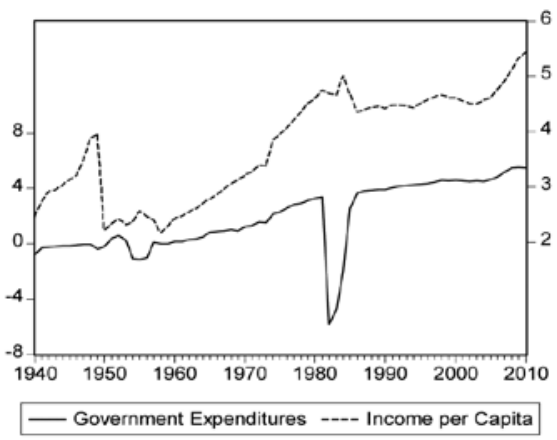

Version 4:

Share of Government Expenditures on Income, Real Income per Capita

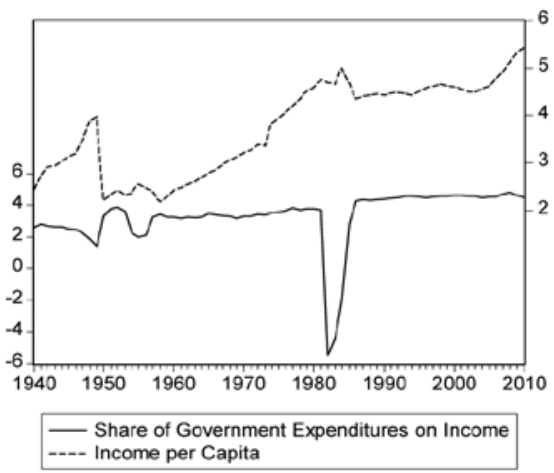

Version 6:

Real Government Expenditures on Infrastructure and Real Income

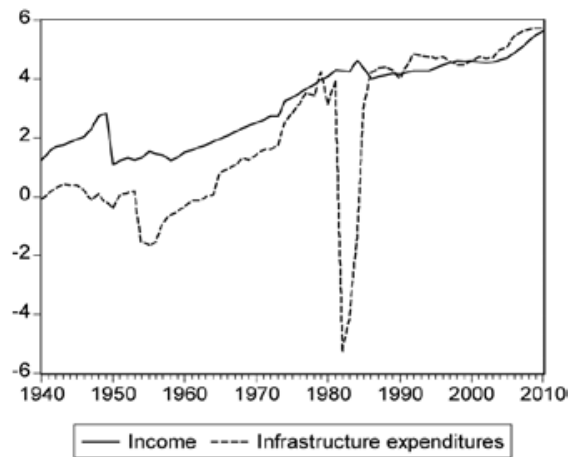

(Continue in next page) 
Figure 1 (continuation)
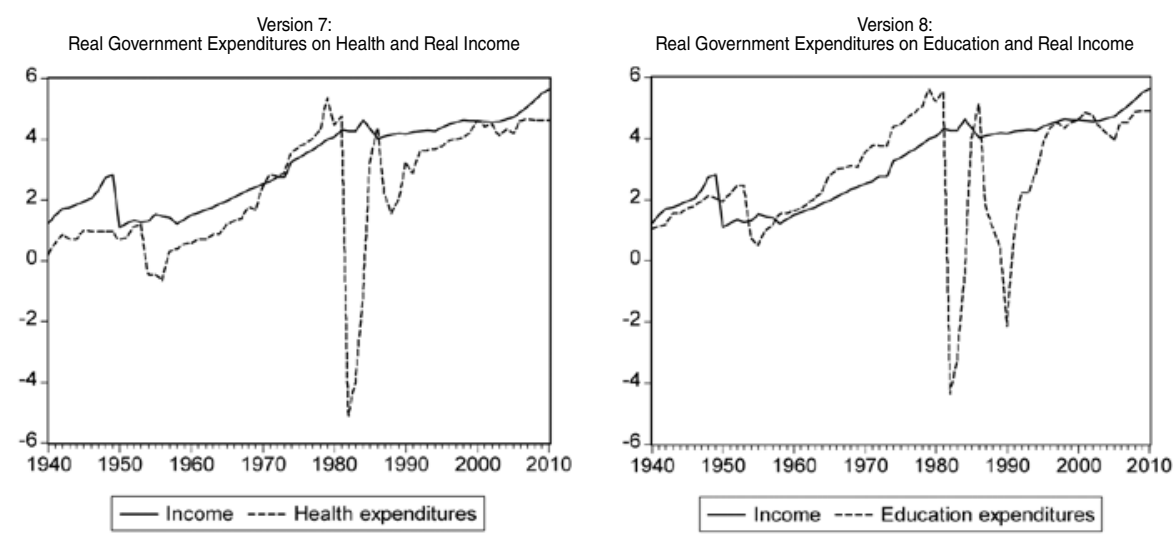

Version 9

Real Government Expenditures on Defense and Real Income

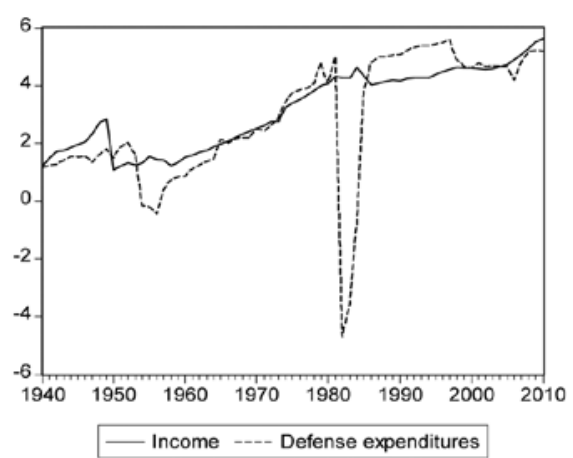

Generally, there seems to exist a high degree of correlation of the variables in most versions of the law. However, the visual correlation between variables lessens in versions four and five, when the share of total government expenditures on income is paired with real GDP per capita and real GDP. A point worth mentioning is that in 1982 government expenditures reached a historical low -as is evident from the graphical representations in Figure 1- largely due to disarray in all government activities caused by the hyperinflation the country experienced during the first part of that decade.

To complement the visual correlations of Figure 1, Table 1 reports pairwise correlations for all variables utilized in this study.

Pairwise correlations confirm that there is a high degree of correlation between various indicators of government intervention and indicators of economic activity. The objective of this study is to probe deeper into these correlations to determine the validity of Wagner's hypothesis with various specifications denoting the relationship between government and income. 


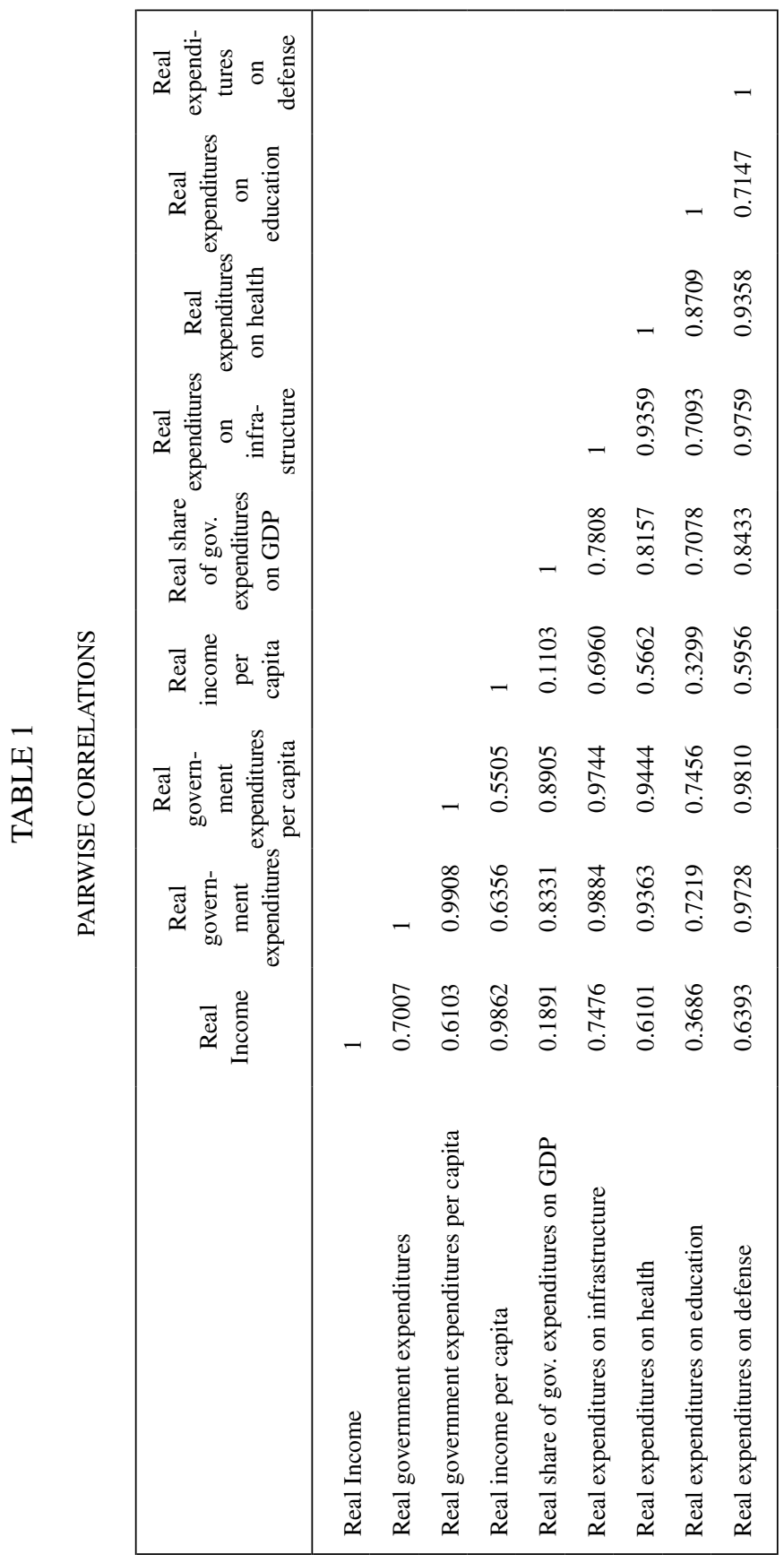




\section{RESULTS}

\section{Unit root tests}

The first step is to analyze the stationary properties of the data in order to determine the order of integration of all variables analyzed. Table 2 reports the results of nonstationary tests for real income (lry), real income per capita (lry/pop), the share of real total government expenditures on real income (lrge/lry), real total government expenditures (lrge), real total government expenditures per capita (lrge/pop), real expenditures on infrastructure (lrginfra), real expenditures on health (lrghealth), real expenditures on education (lrgedu), and real expenditures on defense (lrgdef), using the augmented Dickey-Fuller Tests (ADF test) and the Phillips and Perron (PP test). A constant is included but no time trend in these tests, as recommended by Dickey et al. (1986).

According to the applicable test statistics reported by MacKinnon (1991), the ADF test shows that nonstationarity cannot be rejected for the levels of all variables. When the data are differenced, nonstationarity can be rejected for all data series studied. This indicates that all data series are integrated of order one, or I(1). The results from the PP test generally support the findings with the ADF test and confirm that all of the data series are integrated of order one.

\section{Cointegration tests}

Since unit roots have been confirmed for all data series, there remains the task of determining whether there exists a long-run equilibrium relationship between government expenditures (real total government expenditures, real total government expenditures per capita, share of real total government expenditures on real GDP, real expenditures on infrastructure, health, education, and defense) and income (real GDP and real GDP per capita). In all cointegration tests, an exogenous, inflation dummy variable is included to account for the hyperinflation years of 1982 and 1983. Following the Johansen and Juselius method (1990), a VAR model is estimated and the Johansen Cointegration Test results are presented in Table 3.

Cointegration results for the nine versions of Wagner law demonstrate that there is indeed a long-run equilibrium relationship between government expenditures and income. The Trace statistics for each of the nine versions of the law produce results suggesting the existence of one cointegrating equation at both the 5 percent and 1 percent levels of significance ${ }^{12}$.

\section{Causality tests}

Once cointegration has been confirmed for the nine versions of Wagner's Law, error-correction models, as indicated in equations (9) and (10), can be estimated as a basis for determining causality. Table 4 reports causality test results using ECM models.

12 For the nine versions of the law, the Maximum Eigenvalue test corroborates the results found with the Trace test. 


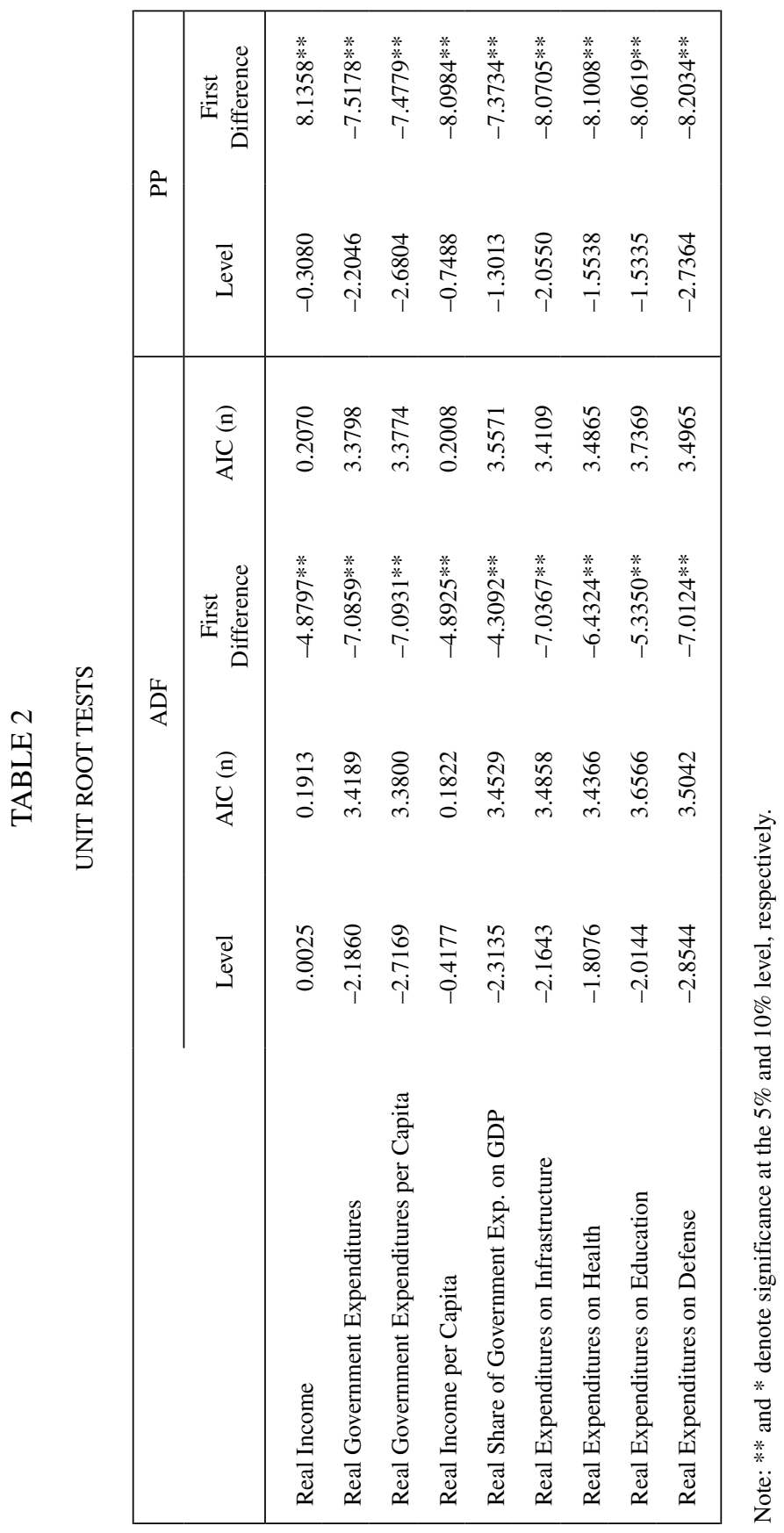




\section{TABLE 3}

\section{COINTEGRATION TEST RESULTS}

\begin{tabular}{|c|c|c|c|}
\hline & $\begin{array}{c}\text { Trace } \\
\text { Statistic }\end{array}$ & $\begin{array}{c}\text { Critical } \\
\text { Value } \\
(5 \%)\end{array}$ & $\begin{array}{c}\text { Critical } \\
\text { Value } \\
(1 \%)\end{array}$ \\
\hline \multicolumn{4}{|c|}{ 1) Government Expenditures, Income (VAR lag=2) } \\
\hline $\begin{array}{l}\mathrm{H}_{0}: \mathrm{r}=0 \\
\mathrm{H}_{0}: \mathrm{r} \leq 1\end{array}$ & $\begin{array}{c}161.69^{* *} \\
2.48\end{array}$ & $\begin{array}{r}18.17 \\
3.74\end{array}$ & $\begin{array}{r}23.46 \\
6.40\end{array}$ \\
\hline \multicolumn{4}{|c|}{ 2) Government Expenditures, Income per Capita (VAR lag=2) } \\
\hline $\begin{array}{l}\mathrm{H}_{0}: \mathrm{r}=0 \\
\mathrm{H}_{0}: \mathrm{r} \leq 1\end{array}$ & $\begin{array}{c}161.42 * * \\
2.37\end{array}$ & $\begin{array}{r}18.17 \\
3.74\end{array}$ & $\begin{array}{r}23.46 \\
6.40\end{array}$ \\
\hline \multicolumn{4}{|c|}{ 3) Government Expenditures per Capita, Income per Capita (VAR lag=2) } \\
\hline $\begin{array}{l}\mathrm{H}_{0}: \mathrm{r}=0 \\
\mathrm{H}_{0}: \mathrm{r} \leq 1\end{array}$ & $\begin{array}{c}161.66^{* *} \\
2.36\end{array}$ & $\begin{array}{r}18.17 \\
3.74\end{array}$ & $\begin{array}{r}23.46 \\
6.40\end{array}$ \\
\hline \multicolumn{4}{|c|}{ 4) Share of Government Expenditures on Income, Income per Capita (VAR lag=2) } \\
\hline $\begin{array}{l}\mathrm{H}_{0}: \mathrm{r}=0 \\
\mathrm{H}_{0}: \mathrm{r} \leq 1\end{array}$ & $\begin{array}{c}161.66^{* *} \\
2.36\end{array}$ & $\begin{array}{r}18.17 \\
3.74\end{array}$ & $\begin{array}{r}23.46 \\
6.40\end{array}$ \\
\hline \multicolumn{4}{|c|}{ 5) Share of Government Expenditures on Income, Income (VAR lag=2) } \\
\hline $\begin{array}{l}\mathrm{H}_{0}: \mathrm{r}=0 \\
\mathrm{H}_{0}: \mathrm{r} \leq 1\end{array}$ & $\begin{array}{c}161.69^{* * *} \\
2.48\end{array}$ & $\begin{array}{r}18.17 \\
3.74\end{array}$ & $\begin{array}{r}23.46 \\
6.40\end{array}$ \\
\hline \multicolumn{4}{|c|}{ 6) Expenditures on Infrastructure, Income (VAR lag=2) } \\
\hline $\begin{array}{l}\mathrm{H}_{0}: \mathrm{r}=0 \\
\mathrm{H}_{0}: \mathrm{r} \leq 1\end{array}$ & $\begin{array}{c}134.19^{* *} \\
2.43\end{array}$ & $\begin{array}{r}18.17 \\
3.74\end{array}$ & $\begin{array}{r}23.46 \\
6.40\end{array}$ \\
\hline \multicolumn{4}{|c|}{ 7) Expenditures on Health, Income (VAR lag=2) } \\
\hline $\begin{array}{l}\mathrm{H}_{0}: \mathrm{r}=0 \\
\mathrm{H}_{0}: \mathrm{r} \leq 1\end{array}$ & $\begin{array}{l}73.53^{* *} \\
2.15\end{array}$ & $\begin{array}{r}18.17 \\
3.74\end{array}$ & $\begin{array}{r}23.46 \\
6.40\end{array}$ \\
\hline \multicolumn{4}{|c|}{ 8) Expenditures on Education, Income (VAR lag=2) } \\
\hline $\begin{array}{l}\mathrm{H}_{0}: \mathrm{r}=0 \\
\mathrm{H}_{0}: \mathrm{r} \leq 1\end{array}$ & $\begin{array}{l}35.23^{* *} \\
2.27\end{array}$ & $\begin{array}{r}18.17 \\
3.74\end{array}$ & $\begin{array}{r}23.46 \\
6.40\end{array}$ \\
\hline \multicolumn{4}{|c|}{ 9) Expenditures on Defense, Income (VAR lag=2) } \\
\hline $\begin{array}{l}\mathrm{H}_{0}: \mathrm{r}=0 \\
\mathrm{H}_{0}: \mathrm{r} \leq 1\end{array}$ & $\begin{array}{c}121.34^{* *} \\
2.24\end{array}$ & $\begin{array}{r}18.17 \\
3.74\end{array}$ & $\begin{array}{r}23.46 \\
6.40\end{array}$ \\
\hline
\end{tabular}

Notes:

1. * and $* *$ denote significance at the $5 \%$ and $1 \%$ level, respectively.

2. $r$ denotes the number of cointegrating vectors.

3. The Schwartz criteria (SC) is used to select the number of lags required in the cointegrating test.

4. All specifications follow a quadratic, deterministic trend.

5. All specifications include an exogenous, inflation dummy to account for the 1982-83 hyperinflation period. 


\section{TABLE 4}

\section{TEST STATISTICS AND PROBABILITIES FOR CAUSALITY TESTS}

(1) Government Expenditures (lrge) and Income (lry)

Cointegrated, hence using ECM model: Bidirectional causality

lrge

$\begin{array}{cc}1 & -0.75^{* *} \\ -1.33 * * & (-6.13) \\ (-4.70) & 1\end{array}$

lry

(2) Government Expenditures (lrge) and Income per Capita (lry/pop)

Cointegrated, hence using ECM model: Bidirectional causality

lrge

$\begin{array}{lc}1 & -0.55^{* *} \\ -1.83 * * & (-5.15) \\ (-3.82) & 1\end{array}$

$\begin{array}{ll}\text { lry/pop } & -1.83^{* *} \\ & (-3.82)\end{array}$

(3) Government Expenditure per Capita (Irge/pop) and Income per Capita (lry/pop) Cointegrated, hence using ECM model: Bidirectional causality

lrge/pop

$1-0.73^{* *}$

lry/pop

$-1.37 * *$

$(-3.29)$

1

(4) Share of Government Expenditures on Income (lrge/lry) and Income per Capita (lry/pop) Cointegrated, hence using ECM model: lrge/lry causes lry/pop

lrge/lry

$1-2.68 * *$

lry/pop

$-0.37$

$(-0.90)$

$(-4.25)$

Share of Government Expenditures on Income (lrge/lry) and Income (lry)

Cointegrated, hence using ECM model: lrge/lry causes lry

lrge/lry

$1-3.03^{* *}$

lry

(6) Expenditures on Infrastructure (lrginfra) and Income (lry)

Cointegrated, hence using ECM model: Bidirectional causality

lrginfra

1

$-0.67 * *$

lry

$-1.49 * *$

1

(7) Expenditures on Health (lrghealth) and Income (lry)

Cointegrated, hence using ECM model: Bidirectional causality

lrghealth
1
$-1.06^{* *}$
(-6.34)

lry 
Table 4 (continuation)

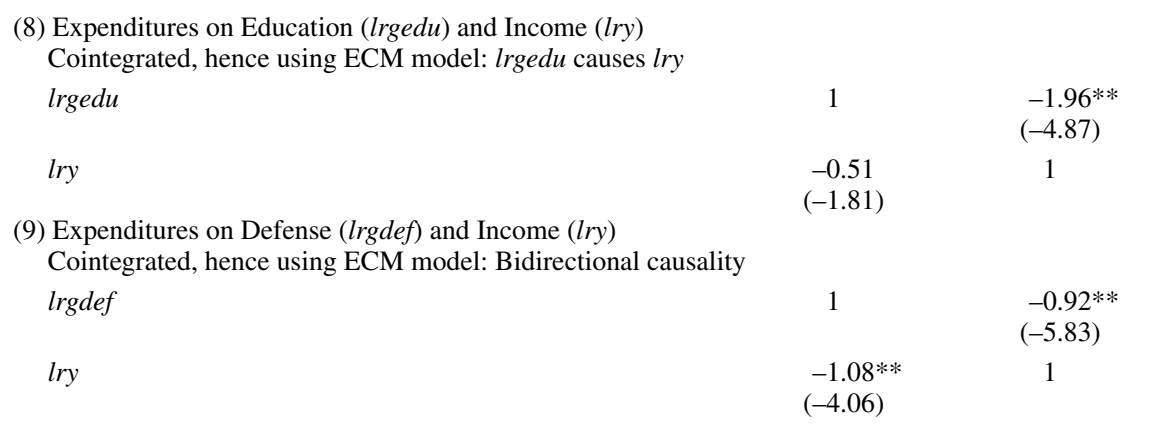

Notes:

1. t-statistics in parentheses.

2. ** indicates significant at the $5 \%$ level of significance.

3. The FPE criterion determined 1 lag length for all causality tests.

As can be observed, bidirectional Granger causality holds for six of the nine versions of the law. However, the effect of income on the various indicators of government expenditures seems stronger -as evidenced by the generally bigger coefficients of lry and lry/pop- which is consistent with Wagner's proposition. In versions four, five and eight, the direction of causality runs from government expenditures (lrge/lry and lrgedu) to income (lry/pop and lry), which does not support Wagner's proposition. As to the specifications with disaggregated government expenditures, the results show that the growth of infrastructure, health, and defense expenditures are explained in terms of Wagner's law.

The findings for versions one through three, six, seven, and nine are consistent with several previous country-specific studies (see, for example, Vatter and Walker (1986), and Yousefi and Abizadeh (1992) for the United States, Ahsan et al. (1996) and Biswal et al. (1999) for Canada, and Chlestos and Kollias (1997) for Greece). They run against the findings of Diamond (1977) and Akitoby et al. (2006), where evidence of Wagner's Law in Bolivia was not found. However, it is believed that the results reported in this study are more reliable than previous ones due to the use of a larger data set and the utilization of more current and comprehensive statistical tools.

\section{CONCLUSIONS}

In this study, nine different versions of Wagner's law have been empirically examined by employing annual time-series data on Bolivia for the period 1940-2010. The analysis is an advance over previous work in several ways. First, the stationarity properties of the data and the order of integration of the data are investigated using 
the Augmented Dickey-Fuller test, the Phillips and Perron test. Second, the hypothesis of a long-run relationship between government expenditures and income is tested using bivariate cointegrated systems and employing the methodology of cointegration analysis. Third, the question of causality is settled using error correction models as the variables in all specifications were found to be cointegrated. Finally, in addition to the five basic specifications proposed by Mann's (1980) and Chang et al. (2004) studies, four other versions of Wagner's law utilizing disaggregated government expenditure data are tested. Of these, the growth in infrastructure, health, and defense expenditures were found to be explained in terms of Wagner's law. Overall, bidirectional Granger causality is found between income and government expenditures in six of the nine versions of the law. However, the effect of income on the various indicators of government expenditures seems stronger, lending credence to Wagner's proposition.

The policy implications of the findings reported here are particularly relevant today, as the administration of Evo Morales is forcefully advancing an agenda where government intervention touches almost every facet of the Bolivian economy. While the results reported in this study may offer a partial justification for such an agenda -as indeed the findings demonstrate bidirectional causality between government actions and economic activity-current policy makers would be advised to remember that not long ago imprudent government interventions caused the worst case of hyperinflation a country ever experienced in times of peace. It would also be judicious to realize that Wagner's proposition implies that with economic growth comes a bigger role for government, not the other way around. Policies whose sole aim is to increase the role of government may in fact cause the opposite results, hence the need for caution and responsibility in determining where and how much government intervention is needed to complement other growth-generating policies.

\section{REFERENCES}

ABIZADEH, S. and J. GRAY (1985). "Wagner's Law: A Pooled Time-Series Cross-Section Comparison", National Tax Journal 88, pp. 209-218.

AFXENTIOU, P.C. and A. SERLETIS (1991). "A Time-Series Analysis of the Relationship between Government Expenditure and GDP in Canada", Public Finance Quarterly 19, pp. 316-333.

AFXENTIOU, P.C. and A. SERLETIS (1996). "Government Expenditures in the European Union: Do They Converge or Follow Wagner's Law", International Economic Journal 10, pp. 33-47.

AFZAL, M. and Q. ABBAS (2010). "Wagner's Law in Pakistan: Another Look", Journal of Economics and International Finance 2 (1), pp. 012-019.

AKAIKE, H. (1974). "A New Look at the Statistical Model Identification", IEEE Transactions on Automatic Control AC-19, pp. 716-723.

AKITOBY, B., B. CLEMENTS, S. GUPTA and G. INCHAUSTE (2006). "Public Spending, Voracity and Wagner's Law in Developing Countries", European Journal of Political Economy 22, pp. 908-924.

AHSAN, S., A. KWAN and B. SAHNI (1996). "Cointegration and Wagner's Hypothesis: Time Series Evidence for Canada", Applied Economics 28, pp. 1055-1058.

ANSARI, M.I., D.V. GORDON and C. AKUAMOAH (1997). "Keynes versus Wagner: Public Expenditure and National Income for Three African Countries", Applied Economics 29, pp. 543-550.

ASSEERY, A., D. LAW and N. PERDIKIS (1999). "Wagner's Law and Public Expenditure in Iraq: A Test using Disaggregated Data", Applied Economic Letters 6, pp. 39-44.

ASHWORTH, J. (1994). "Spurious in Mexico: A Comment on Wagner's Law", Public Finance 49 (2), pp. 282-286. 
BISWAL, B., U. DHAWAN and H.-Y. LEE (1999). "Testing Wagner versus Keynes using Disaggregated Public Expenditure Data for Canada", Applied Economics 31, pp. 1283-1291.

CHANG, T., W. LIU and S.B. CAUDILL (2004). "A re-examination of Wagner's law for ten countries based on cointegration and error-correction modeling techniques", Applied Financial Economics 14 , pp. 577-589.

CHLETSOS, M. and C. KOLLIAS (1997). "Testing Wagner's Law Using Disaggregated Public Expenditure Data in the Case of Greece: 1958-93", Applied Economics 29 (3), pp. 371-377.

DIAMOND, J. (1977). "Wagner's "Law" and the Developing Countries", The Developing Economies 15 (1), pp. 37-59.

DICKEY, D.A. and W.A. FULLER (1979). "Distribution of the Estimators for Autoregressive Time Series with a Unit Root", Journal of American Statistical Association 74, pp. 427-431.

DICKEY, D.A. and W.A. FULLER (1981). "Likelihood Ratio Statistics for Autoregressive Time Series with a Unit Root", Econometrica 49 (4), pp. 1057-1072.

DICKEY, D.A., W. BELL and R. MILLER (1986), "Unit Roots in Time Series Models: Tests and Implications", The American Statistician 40 (1), pp. 12-26.

ENGLE, R.F. and C.W. GRANGER (1987). "Co-integration and Error-Correction: Representation, Estimation and Testing", Econometrica 55, pp. 251-276.

ENGLE, R.F. and B. YOO (1987). "Forecasting and Testing in Cointegrated Systems", Journal of Econometrics 35, pp. 143-159.

FLORIO, M. and S. COLAUTTI (2005). "A Logistic Growth Theory of Public Expenditures: A Study of Five Countries over 100 Years", Public Choice 122, pp. 355-393.

GANDHI, V.P. (1971). "Wagner's Law of Public Expenditure: Do Recent Cross-Section Studies confirm it?", Public Finance 26, pp. 44-56.

GRANGER, C.W. (1986). "Developments in the Study of Cointegrated Economic Variables", Oxford Bulletin of Economics and Statistics 48, pp. 213-228.

GRANGER, C.W. and P. NEWBOLD (1974). "Spurious Regression in Econometrics", Journal of Econometrics 2, pp. 111-120.

HALICIOGLU, F. (2003). “Testing Wagner's Law for Turkey, 1960-2000”, Review of Middle East Economics and Finance 1 (2), pp. 129-141.

HAYO, B. (1994). "No Further Evidence of Wagner's Law for Mexico", Public Finance 49 (2), pp. 287-294.

HONDROYIANNIS, G. and E. PAPAPETROU (1995). "An Examination of Wagner's Law for Greece: A Cointegration Analysis", Public Finance 50, pp. 67-79.

HSIAO, C. (1979a). "Autoregressive Modeling of Canadian Money and Income Data", Journal of the American Statistical Association 74 (367), pp. 553-560.

HSIAO, C. (1979b). "Causality Tests in Econometrics", Journal of Economic Dynamics and Control 4, pp. 321-346.

HSIAO, C. (1981). "Autogressive modeling and Money-Income Causality Detection", Journal of Monetary Economics 7, pp. 85-106.

IYARE, S. and T. LORDE (2004). "Cointegration, Causality and Wagner's Law: Tests for Selected Caribbean Countries", Applied Economic Letters 11 (13), pp. 815-825.

JOHANSEN, S. (1988). "Statistical Analysis of Cointegration Vectors", Journal of Economic Dynamics and Control 12, pp. 231-254.

JOHANSEN, S. (1994). "Testing Weak Exogeneity and the Order of Cointegration in UK Money Demand Data", Journal of Policy Modelling 14, pp. 313-334.

JOHANSEN, S. and K. JUSELIUS (1990). "Maximum Likelihood Estimation and Inference on Cointegration - with Applications to the Demand for Money", Oxford Bulletin of Economics and Statistics 52, pp. 169-210.

KWIATKOWSKI, D.P., C. PHILLIPS, P. SCHMIDTH and Y. SHIN (1992). "Testing the Null Hypothesis of Stationarity against the Alternative of a Unit Root", Journal of Econometrics 1, pp. 159-178.

LIN, C-A. (1995). "More Evidence on Wagner's Law for Mexico", Public Finance 50 (2), pp. 262-277.

MacKINNON, J. (1991). Critical Values for Cointegration Tests in Long-Run Economic Relationships, in Readings in Cointegration (Eds), Engle, R. and C. Granger, Oxford University Press, New York, pp. 267-276.

MAGAZZINO, C. (2010). Wagner's Law and Italian Disaggregated Public Spending: Some Empirical Evidences, MPRA Paper No. 26662. 
MANN, A.J. (1980). “Wagner's Law: An Econometric Test for Mexico”, National Tax Journal 33, pp. $189-201$.

MURTHY, V. (1993). "Further Evidence of Wagner's Law for Mexico: An Application of Cointegration Analysis", Public Finance 48 (1), pp. 92-96.

NAGARAJAN, P. and A. SPEARS (1990). “An Econometric Test of Wagner's Law for Mexico: A Reexamination", Public Finance 1, pp. 165-168.

NARAYAN, P.K., I. NIELSEN and R. SMYTH (2008). "Panel Data, Cointegration, Causality and Wagner's Law: Empirical Evidence from Chinese Provinces”, China Economic Review 19 (2), pp. 297-307.

PHILLIPS, P.C. and P. PERRON (1988). "Testing for a Unit Root in Time Series Regression", Biometrika 75, pp. 335-346.

RAM, R. (1986). "Causality between Income and Government Expenditure: A Broad International Perspective", Public Finance 3, pp. 393-413.

REHMAN, J., A. IQBAL and W. SIDDIQI (2010). "Cointegration-Causality Analysis between Public Expenditures and Economic Growth in Pakistan”, European Journal of Social Sciences 13 (4), pp. 556-565.

TANO, D.K. (1993). "The Added Worker Effect: A Causality Test”, Economic Letters 43, pp. 111-117.

THORNTON, J. (1999). "Cointegration, Causality and Wagner's Law in Nineteenth Century Europe", Applied Economic Letters 6, pp. 413-416.

TOBIN, D. (2005). "Economic Liberalization, the Changing Role of the State and Wagner's Law: China's Development since 1978", World Development 33, pp. 729-743.

VATTER, H.G. and J.F. WALKER (1986). "Real Public Sector Employment Growth, Wagner's Law, and Economic Growth in the United States", Public Finance 1, pp. 117-137.

WAGNER, A. (1883). Grundlegung der Politischen Ökonomie, $3^{\text {rd }}$ Edition, Leipzig: C. F. Winter.

YOUSEFI, M. and S. ABIZADEH (1992). "Growth of State Government Expenditures: Empirical Evidence from the United States", Public Finance 47 (2), pp. 322-239.

ZHENG, Y., J. LI, X-L. WANG and C. LI (2010). "An Empirical Analysis of the Validity of Wagner's Law in China: A Case Study Based on Gibbs Sampler", International Journal of Business Management 5 (6), pp. 161-168. 
